\title{
Urban Ecosystem Services: Current Knowledge, Gaps, and Future Research
}

\author{
Alessio Russo ${ }^{1, *(D)}$ and Giuseppe T. Cirella ${ }^{2}$ (D) \\ 1 School of Arts, Francis Close Hall Campus, University of Gloucestershire, Swindon Road, Cheltenham GL50 \\ $4 \mathrm{AZ}, \mathrm{UK}$ \\ 2 Faculty of Economics, University of Gdansk, 81-824 Sopot, Poland; gt.cirella@ug.edu.pl \\ * Correspondence: arusso@glos.ac.uk; Tel.: +44-(0)12-4271-4557
}

Citation: Russo, A.; Cirella, G.T.. Urban Ecosystem Services: Current Knowledge, Gaps, and Future Research. Land 2021, 10, 811. https:/ / doi.org/10.3390/land10080811

Received: 28 July 2021

Accepted: 30 July 2021

Published: 1 August 2021

Publisher's Note: MDPI stays neutral with regard to jurisdictional claims in published maps and institutional affiliations.

Copyright: (c) 2021 by the authors Licensee MDPI, Basel, Switzerland. This article is an open access article distributed under the terms and conditions of the Creative Commons Attribution (CC BY) license (https:// creativecommons.org/licenses/by/ $4.0 /)$.
The term ecosystem services was coined to describe the societal benefit that natural ecosystems provide, as well as to raise awareness about biodiversity and ecosystem conservation [1]. Nowadays, with most people living in cities (i.e., over 50\%) and the challenges that come with it, such as the urban heat island effect, food security, floods, pollution, and so on, the concept of ecosystem services is linked to the built environment's sustainability and livability [2,3]. Cities have long been one of the least researched ecosystems in this regard [4]. Consequently, there is a growing interest in urban ecology as well as in urban ecosystem services (UES) that present solutions to the above issues within the environment of the cityscape [2,4]. The need to study these "novel" ecosystems can mitigate the effects of the growing urban population and rural-to-urban transition. In this context, following the first special issue on UES [5], this second special issue aims to update existing knowledge and identify gaps and potential areas for future research. This second issue, in particular, has 10 peer-reviewed papers authored by scholars from all over the world, spanning five continents (Figure 1).

The structure of this article is to look at the current knowledge-base, point out gaps, and summarize future research findings within the dimension of UES. Lourdes et al. [6] point out that research on UES in the Global South has not been extensively examined as it has been in the Global North. To address this issue, they conducted a systematic literature review of UES in Southeast Asia over a two-decade period [6]. Their findings emphasize the region's unequal distribution of UES research and highlight common services, scales, and characteristics examined, as well as methodologies used [6]. They identified that while most research analyze regulatory and cultural UES at a landscape scale, few studies looked at interconnections between services by evaluating synergies and tradeoffs [6]. Their results also suggest the urgent need for multitemporal and scenario-based research on the resilience of UES provision [6]. The researchers concluded that more research is needed to incorporate a variety of monetary and non-monetary valuations, as well as increased stakeholder involvement in UES assessments, so that the valuation of UES can encourage more transparent tradeoff assessments to support sustainable city planning [6]. In the Global South, there is also little evidence available on how people perceive the benefits and costs of urban green spaces [7]. To fill this gap, Pineda-Guerrero et al. [7] used semi-structured surveys, statistical analyses, and econometrics to investigate user perceptions of governance and the benefits and costs, i.e., ecosystem services and ecosystem disservices, provided by neotropical green areas in Bogota, Colombia, as well as their willingness to invest in their conservation. Despite the sub-severe watershed's stormwater runoff concerns, their modeling reveals that air quality and biodiversity are very important advantages while water control is not [7]. In terms of costs, inadequate levels of maintenance and infrastructure in the investigated green areas were linked to a sense of insecurity due to crime. The community's unwillingness to invest (UTI) in green space protection was impacted by their perceptions of government openness, corruption, and performance [7]. The findings indicate that socioeconomic backgrounds, government 
performance, and environmental education all influence the value or priority individuals have on the benefits, costs, and UTI of conservation efforts in urban green spaces [7].

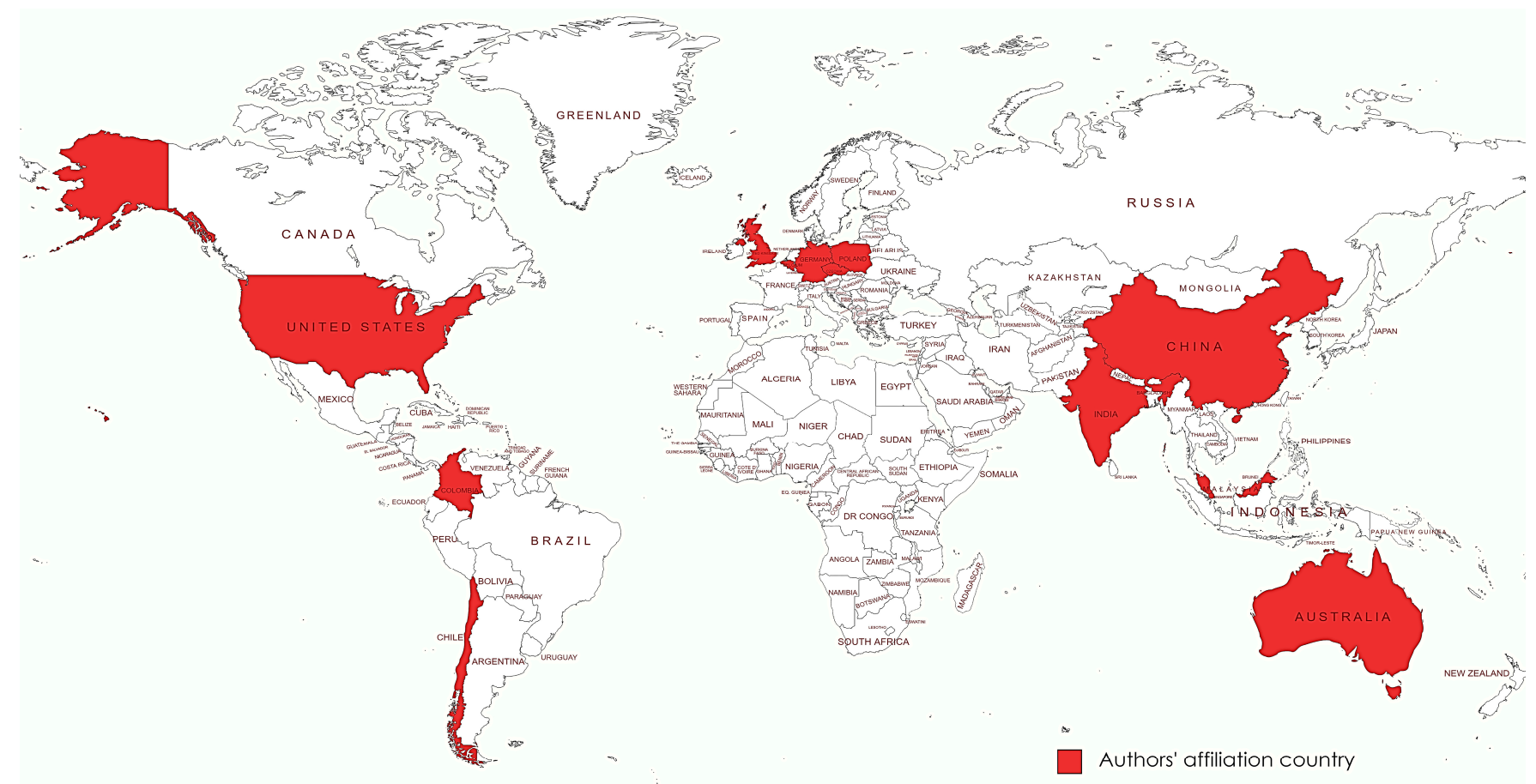

Figure 1. Authors' affiliation country. Source: Created using MapChart.net.

Animals play an important role in providing ecosystem services in cities. Conserving animal populations that offer faunal ecosystem services is critical to ensuring that ecosystems continue to operate properly and provide ecosystem services where there is a need for them [8]. For example, birds provide a variety of ecosystem services and are some of the most successful urban adapters [9]. Based on a literature review of research conducted between 1979 and 2020, Patankar et al. [9] reviewed research studies on traits that influence the survival and response of birds to urbanization, identifying the state of current knowledge, highlighting key knowledge gaps, and identifying geographic and species-specific disparities in research that require specific focus. There is still a gap in the scientific literature on how people perceive urban forestry and related ecosystem services [10]. The research of Alves Carvalho Nascimento and Shandas [10] intended to address this gap by looking at how neighborhood trees and socioeconomic factors affect public perceptions of ecosystem service availability. They studied socioeconomic factors, land cover statistics, and public opinions of neighborhood trees in Portland, OR. The findings showed a strong link between tree canopy, resident income, and sense of responsibility for urban forestry, based on over 2500 survey responses [10]. While a body of literature highlights the importance of trees in delivering UES (e.g., pollination, air quality, carbon storage and sequestration, temperature mitigation, etc.) [11-13], their survey findings show that management and cultural ecosystems services are important to respondents [10]. This finding, while seemingly insignificant, is relevant for several reasons, including the fact that respondents appear to be aware of the financial and maintenance costs associated with trees [10].

Across the globe, land-based financing is becoming more widely recognized as a mechanism for developing infrastructure and supplying ecosystem services [14]. One of the main drivers of urban ecosystem growth in many nations has been a fast increase in land and property values. This occurrence has given project proponents and policymakers with a plethora of alternatives and problems, prompting them to construct or incorporate land-based finance components into their policies and regulations. In particular, the Indian 
government and state governments have attempted to monetize land through a variety of methods in order to improve the financial sustainability of infrastructure and area development projects. In terms of land monetization approaches, Tirumala and Tiwari [14] examined Indian central and state infrastructure policies and relating acts. Key factors of a successful strategy that captures a rise in land values are highlighted and reported on in their study [14]. Zepp and Inostroza [15] created an ad-hoc assessment to evaluate a typical environmental compensation technique using ecosystem services with an actual planning and development scenario involving a planned route to a restructured former industrial site in Bochum, Germany. The researchers used both techniques to assess the impact of the proposed construction choices [15]. In a subsequent phase, they chose the alternative with the lowest effect and calculated the ecosystem service losses from the compensatory measures [15]. The findings demonstrate that an ecosystem services evaluation offers a sound foundation for selecting development alternatives, identifying compensation areas, and estimating compensation amounts, with the added advantage of enhancing the environmental quality of the impacted areas [15]. When utilizing Zepp and Inostroza's method, there are two main limitations to consider. The first limitation is that they utilized a broad outline of the proposed roadways. In a more comprehensive analysis, the exact demarcation as described in engineering drawings should be used [15]. The second limitation is that they did not examine the area compensated in terms of urban structural subtypes in great depth. In general, adding nature-based solutions to existing urban settings may always enhance the provision of ecosystem services [15]. However, depending on the morphology of the city, a more precise estimate is required [15].

Greening tram lanes in cities appear to be an important strategy for the development of green corridors as well as enhancing UES [16]. Łukaszkiewicz et al. [16] demonstrated how to revitalize the Warsaw cityscape by converting existing tram lines where viable and developing new ones from a "green perspective." Green tram lanes reduce the noise level during tram operation, improve the aesthetic experience of city streets, and, when skillfullyapplied, allow the sound level from traffic to be reduced by 10.0 to $15.0 \mathrm{~dB}$ [16]. Their research exemplifies future UES-based thinking and moves the bar on how infrastructure, design, and planning come together in a 21st century city. Expanding on this unity-concept, Wang et al. [17] used multiperiod datasets from the Land Use and Land Cover of China databases to study farmland loss owing to urbanization in China's Guangdong-Hong Kong-Macao Greater Bay Area from 1980 to 2018. Then, using valuation methodologies, they produced agricultural ecosystem service values (ESVs) to quantify the ecosystem service changes induced by urbanization in the research region [17]. The findings revealed that over the last 38 years, urbanization has resulted in a total area of farmland loss of $3711.3 \mathrm{~km}^{2}$, resulting in a direct decrease in total ESVs of 5036.7 million yuan [17]. A sense of urbanization urgency pinpoints the need for better UES knowledge and how the cityscape is growing and changing. Due to this urban upsurge, landscape architects are under increasing strain and require practical knowledge, skills, and methodologies to support their designs [18]. Cultural ecosystem services (CES) have been linked to landscape architecture research, and the findings of CES assessments have the potential to help landscape architecture practice [18]. However, there have been few attempts to investigate CES in landscape architecture research in a systematic manner [18]. Furthermore, how CES assessments are carried out in in landscape architecture studies are rarely investigated. The goal of Cheng et al.'s [18] study points out some of these challenges and recommends employing CES assessments in landscape architecture practice, with an emphasis on landscape architecture design [18]. In the last paper, Russo et al. [19] used Bristol City Centre as an example to illustrate two free user-friendly web resources (i.e., i-Tree Canopy and the Office for National Statistics). They showed that both tools are simple to use and effectively convey ecosystem services and monetary values. Their research has updated the literature on the evaluation of green infrastructure tools in the United Kingdom, as well as identified topics for further research. As such, important UES gains have been made in the past year in which researchers have had to ponder and work within the new COVID-19 
era. These abrupt changes have resulted in some UES rethinking, as demonstrated in this article, and from the new work environments city planners and urbanists have faced.

Author Contributions: Visualization and writing—original draft preparation, A.R.; writing-review and editing, A.R. and G.T.C. Both authors have read and agreed to the published version of the manuscript.

Funding: This research received no external funding.

Institutional Review Board Statement: Not applicable.

Informed Consent Statement: Not applicable.

Data Availability Statement: Not applicable.

Acknowledgments: We are grateful to the MDPI Land team of academic editors and reviewers for assisting with the Special Issue's academic excellence. MapChart.net was used to create the authors' affiliation country.

Conflicts of Interest: The authors declare no conflict of interest.

\section{References}

1. Birkhofer, K.; Diehl, E.; Andersson, J.; Ekroos, J.; Früh-Müller, A.; Machnikowski, F.; Mader, V.L.; Nilsson, L.; Sasaki, K.; Rundlöf, M.; et al. Ecosystem services-Current challenges and opportunities for ecological research. Front. Ecol. Evol. $2015,2,87$. [CrossRef]

2. Russo, A.; Cirella, G.T. Urban Sustainability: Integrating Ecology in City Design and Planning. In Sustainable Human-Nature Relations: Environmental Scholarship, Economic Evaluation, Urban Strategies; Cirella, G.T., Ed.; Springer Singapore: Singapore, 2020; pp. 187-204. ISBN 978-981-15-3049-4.

3. Russo, A.; Cirella, G.T. Edible urbanism 5.0. Palgrave Commun. 2019, 5, 1-9. [CrossRef]

4. Stott, I.; Soga, M.; Inger, R.; Gaston, K.J. Land sparing is crucial for urban ecosystem services. Front. Ecol. Environ. 2015, 13, 387-393. [CrossRef]

5. Russo, A.; Cirella, G.T. Urban ecosystem services: New findings for landscape architects, urban planners, and policymakers. Land 2021, 10, 88. [CrossRef]

6. Lourdes, K.; Gibbins, C.; Hamel, P.; Sanusi, R.; Azhar, B.; Lechner, A. A review of urban ecosystem services research in southeast asia. Land 2021, 10, 40. [CrossRef]

7. Pineda-Guerrero, A.; Escobedo, F.J.; Carriazo, F. Governance, nature's contributions to people, and investing in conservation influence the valuation of urban green areas. Land 2020, 10, 14. [CrossRef]

8. Gutierrez-Arellano, C.; Mulligan, M. A review of regulation ecosystem services and disservices from faunal populations and potential impacts of agriculturalisation on their provision, globally. Nat. Conserv. 2018, 30, 1-39. [CrossRef]

9. Patankar, S.; Jambhekar, R.; Suryawanshi, K.R.; Nagendra, H. Which traits influence bird survival in the city? A review. Land 2021, 10, 92. [CrossRef]

10. Alves Carvalho Nascimento, L.; Shandas, V. Integrating diverse perspectives for managing neighborhood trees and urban ecosystem services in portland, OR (US). Land 2021, 10, 48. [CrossRef]

11. Roy, S.; Byrne, J.; Pickering, C. A systematic quantitative review of urban tree benefits, costs, and assessment methods across cities in different climatic zones. Urban. For. Urban. Green. 2012, 11, 351-363. [CrossRef]

12. Speak, A.; Escobedo, F.J.; Russo, A.; Zerbe, S. Total urban tree carbon storage and waste management emissions estimated using a combination of LiDAR, field measurements and an end-of-life wood approach. J. Clean. Prod. 2020, 256, 120420. [CrossRef]

13. Salmond, J.A.; Tadaki, M.; Vardoulakis, S.; Arbuthnott, K.; Coutts, A.; Demuzere, M.; Dirks, K.N.; Heaviside, C.; Lim, S.; Macintyre, H.; et al. Health and climate related ecosystem services provided by street trees in the urban environment. Environ. Health 2016, 15, S36. [CrossRef] [PubMed]

14. Tirumala, R.D.; Tiwari, P. Land-based financing elements in infrastructure policy formulation: A case of india. Land 2021, 10, 133. [CrossRef]

15. Zepp, H.; Inostroza, L. Who pays the bill? Assessing ecosystem services losses in an urban planning context. Land 2021, 10, 369. [CrossRef]

16. Łukaszkiewicz, J.; Fortuna-Antoszkiewicz, B.; Oleszczuk, Ł.; Fialová, J. The potential of tram networks in the revitalization of the warsaw landscape. Land 2021, 10, 375. [CrossRef]

17. Wang, X.; Yan, F.; Zeng, Y.; Chen, M.; He, B.; Kang, L.; Su, F. Ecosystem Services changes on farmland in response to urbanization in the Guangdong-Hong Kong-Macao greater bay area of china. Land 2021, 10, 501. [CrossRef]

18. Cheng, X.; Van Damme, S.; Uyttenhove, P. Applying the evaluation of cultural ecosystem services in landscape architecture design: Challenges and opportunities. Land 2021, 10, 665. [CrossRef]

19. Russo, A.; Chan, W.T.; Cirella, G.T. Estimating air pollution removal and monetary value for urban green infrastructure strategies using web-based applications. Land 2021, 10, 788. [CrossRef] 